\title{
Amines: possible causative agents in the development of bronchial hyperreactivity in workers manufacturing polyurethanes from isocyanates
}

\author{
L BELIN, ${ }^{1}$ U WASS, ${ }^{1}$ G AUDUNSSON, ${ }^{2}$ AND L MATHIASSON ${ }^{2}$ \\ From the Occupational Allergy Unit, ${ }^{1}$ Department of Medicine I, Sahlgren's Hospital, S-413 45 Göteborg, \\ and Analytical Chemistry, ${ }^{2}$ Chemical Centre, University of Lund, S-220 07 Lund, Sweden
}

ABSTRACT Investigations of respiratory symptoms among workers in a factory producing polyurethane foam included measurement of air pollution with amines and isocyanates and a simultaneous health investigation of the exposed workers. An increased bronchial reactivity to inhaled methacholine was found in the study group compared with two unexposed control groups. This finding, together with visual disturbances in the exposed group, were assumed to be caused mainly by the volatile amines. The concentrations of isocyanates in air were well below $0.005 \mathrm{ppm}$. The amine concentration was 1000 to 10000 times higher than the isocyanate concentration. The most volatile amine, $\mathrm{N}$-methylmorpholine, occurred in the air in concentrations higher than $10 \mathrm{ppm}$. The results indicate that not only the isocyanates but also the amines might well be responsible for respiratory symptoms among exposed workers in polyurethane foam production.

During the past 20 years polyurethanes have gained increasing industrial importance due to their excellent chemical and mechanical properties. They are made by reacting isocyanates with polyols (polyalcohols) in the presence of amines as catalysts and cross linking agents.

The occupational health problems associated with polyurethane production are mainly ascribed to the occurrence of isocyanates in the working atmosphere. The ability of isocyanates to cause bronchial hypersensitivity reactions is well known. ${ }^{1-10}$ The underlying mechanism is not fully understood, however, and the bronchial reactivity may be due to chemically irritant, immunological, or pharmacological mechanisms. Isocyanate-specific IgE antibodies have occasionally been shown in serum from sensitised workers. ${ }^{1-19}$

During the past five years we have studied adverse health effects associated with the production of polyurethanes. Several cases of isocyanate asthma have been diagnosed during that time, and we have also found antibodies to isocyanates in some of the patients when using a modified RAST (radio-

Received 22 February 1982

Accepted 16 February 1983 allergosorbent test) method (L Belin and U Wass, unpublished data).

In some factories producing polyurethanes, especially those using MDI $\left(4,4^{\prime}\right.$-Diphenylmethane diisocyanate), workers claimed to have respiratory symptoms although we found only very low levels of isocyanates $(<0.0001 \mathrm{ppm})$, including phenyl isocyanate, in the working atmosphere when using a modern liquid chromatographic method for the analysis. ${ }^{20}$ This suggested the presence of respiratory tract irritants other than isocyanates in the working environment. Polyols are considered to have only a weak irritant effect on the airways mainly because of their low vapour pressures which limit the exposure by inhalation. Amines, on the other hand, are often volatile and are known respiratory irritants. ${ }^{21-27}$ Thus dimethyl ethanol amine has been reported specifically to induce asthma and rhinitis in a spray painter. ${ }^{24}$ Furthermore, a group of 25 workers showed a significant decrease in lung function over a workshift when exposed to 3-dimethylamino propylamine (3-DMAPA). ${ }^{25}$ Late asthmatic reactions can be caused by amines such as ethylenediamine and piperazine. ${ }^{2627}$ It was therefore natural to focus attention not only on the isocyanates but also on these strong basic and polar substances. To our knowledge, no reports on respiratory effects from 
amines used in polyurethane production have been published. One reason for this may be the limited knowledge of the air concentrations in this type of production, because of the lack of a good sampling procedure and analytical methods for determining trace amounts of amines. Recent developments in amine analysis have altered this situation. It is now possible to analyse free amines by gas liquid chromatography (GLC) directly at sub ppm levels by injecting alkalised aqueous solutions containing the collected amines (G Audunsson and L Mathiasson, unpublished data). Isocyanates, being hydrolysed to corresponding amines, can be determined by GLC after alkalisation and extraction with toluene giving 10 times enrichment down to a level of about $0.5 \mathrm{ppb}$ (which is $5 \%$ of the Swedish threshold limit value) in a 251 air sample. $27 \mathrm{a}$

The factory at which this study was carried out had a total work force of $\mathbf{4 0 0}$ individuals and produced a variety of plastic products for the car industry, including polyurethane foam car seats. About 50 workers were engaged in polyurethane production, which started in 1972. The company doctor and his nurse had gained the clinical impression that there was an increased incidence of respiratory symptoms among the 50 workers engaged in the foam seat production. A study made in 1979 showed air levels of TDI ranging from 2 to $5 \mathrm{ppb}$ in 15 minute samples and 1 to $2 \mathrm{ppb}$ as an average over a work shift (a total of 34 samples was taken). Over a six year period, three workers had been transferred to other jobs because of symptoms of asthma. To reduce the risk, people with strong atopy and with a history of respiratory dysfunction had not been allowed to work in this part of the factory.

The purpose of this investigation was to identify causative agents for respiratory and other symptoms among the workers. Thus the investigation consisted of a medical examination of the workers and simultaneous determination of air levels of isocyanates and amines.

\section{Manufacturing process}

A commercial mixture of approximately $90 \%$ TDI (monomers and trimers of 2,4- and 2,6-toluene diisocyanate) and $10 \% \mathrm{MDI}$ was used and the amines $\mathrm{N}$-methylmorpholine and DABCO (1,4-diazabicyclo- $(2,2,2)$ octane) were added to a concentration of about $1 \%$ as catalysts. The reactants were transferred from bulk storage tanks through a system of valves and pipes to a series of two part moulds. The moulds were automatically filled with the reactants and moved on a conveyor track through a heated tunnel. This system prevented direct contact with the unreacted isocyanates. Occasionally, due to technical failure, the moulds may be incompletely filled with polyols, leaving an excess of unreacted isocyanates. The frequency of such near accidents was about one or two incidents a month. The foaming area was, however, equipped with powerful extraction fans, and the workers removing the isocyanates wore face masks for respiratory protection. The manual work was limited to three operations: (A) moulded items were taken out and supporting steel wires were inserted in the empty moulds; (B) the items were transferred to a vacuum chamber in order to break the walls of the polyurethane cells; and (C) excess foam was removed from the moulded seats in an adjacent room with the aid of pneumatic scissors. The workers circulated regularly between operations.

\section{Methods}

\section{MEDICAL EXAMINATION}

Forty eight subjects who had been exposed to isocyanates and amines answered a questionnaire under the guidance of one interviewer (LB).

By skin prick testing, those who developed immediate weal and flare reactions to one or more of the common aeroallergen extracts were classified as atopic subjects. The prick test panel included two isocyanate-HSA conjugates (MDI,TDI) that were also used in a RAST system to detect specific IgE antibodies in the serum. Methacholine inhalation challenges were performed by tidal breathing through a face mask of an aerosol containing first 1 $\mathrm{mg}$ and then $10 \mathrm{mg}$ of methacholine (acetyl- $\beta$ methylcholine chloride) generated by a Pari optimal nebuliser. One millilitre of each test solution was given by intermittent nebulisation over the inspiration. Each step was separated by a five minute observation period, including spirometry, and was preceded by a placebo challenge using $1 \mathrm{ml}$ of saline. Forced expirations after maximal inspiration were recorded with an electronic Monagan M 403 spirometer to which a Houston $X-Y$ recorder was connected. FEV 1 was directly read on a display and $\mathrm{MEF}_{40}$ (maximum expiratory flow when $40 \%$ of prechallenge vital capacity remained) was calculated from the flow volume curves produced by this instrument, assuming TLC (total lung capacity) to be unchanged throughout the test procedure. Thirty controls, matched for age and smoking but otherwise randomly selected, were taken from a workforce engaged in injection moulding of thermosetting materials (plastics) in an adjacent building. These controls (first control group) were not exposed to either isocyanate or amines but were occasionally exposed to fumes from heated thermo- 
setting materials. They were treated in the same way as the polyurethane workers. To estimate the intraindividual variations in the spirometric parameters and to define low bronchial reactivity to 10 $\mathrm{mg}$ of inhaled methacholine, a second control group consisting of 24 healthy non-smoking subjects associated with our laboratory were selected. This group may reflect a "superhealthy" population because the criteria for entering the group were: no respiratory symptoms, no smoking, and no clinical signs of atopy.

\section{ANALYSIS OF THE WORKING ATMOSPHERE}

Isocyanates were sampled and analysed as described by Sangö and Zimerson. ${ }^{20}$ Briefly, air was drawn through a midget impinger filled with $10 \mathrm{ml}$ of reagent absorber solution at a flow rate of $1 \cdot 0-1 \cdot 51 / \mathrm{min}$. The isocyanates form stable derivatives with this reagent (9-(N-methylaminomethyl)-anthracene). The derivatives were analysed using high performance liquid chromatograpy (HPLC). The detection limit was about $0 \cdot 1 \mathrm{ppb}$, based on a 151 air sample. The collection efficiency was more than $95 \%$.

The amines were sampled in impinger vessels containing $0.1 \quad \mathrm{~N} \quad \mathrm{H}_{2} \mathrm{SO}_{4}$. After alkalisation, $\mathrm{N}$-methylmorpholine and DABCO were determined by direct injection. Hydrolysed TDI was determined after extraction of the alkalised amine solution. The relative standard deviation in the total analysis of triple injections of samples into the gas chromatograph was $5 \%$ in the first place and $8 \%$ in the analysis of TDI. The chromatographic measurements were made on a Varian 3700 gas chromatograph equipped with a Varian nitrogen sensitive detector (TSD) and an HP $3390 \mathrm{~A}$ integrator. This analysis is a further development of methods previously published by us. ${ }^{28} 29$

\section{Results}

\section{CLINICAL FINDINGS}

Analysis of the relative standard deviation for the intraindividual variation of $F E V_{1}$ and $\mathrm{MEF}_{40}$ in the second control group (healthy, non-smoking individuals) showed that a decrease from baseline must be greater than $15 \%$ and $30 \%(>2 \mathrm{CV} \sqrt{2})$ respectively to be considered a significant ventilatory change. No one in the second control group had a reaction beyond these levels when challenged with 1 $\mathrm{mg}$ and $10 \mathrm{mg}$ of methacholine. Thus individuals having a change from baseline of less than $15 \%$ for $\mathrm{FEV}_{1}$ and $30 \%$ for $\mathrm{MEF}_{40}$ when challenged with 1 $\mathrm{ml}$ of a $10 \mathrm{mg} / \mathrm{ml}$ solution were classified as having a low methacholine reactivity. This group will also include individuals having no response to methacholine, but for statistical reasons (intraindividual variation) it was not possible to distinguish non-responders from low responders. We chose a $25 \%$ decrease in $\mathrm{FEV}_{1}$ as the lower limit for increased reactivity. This limit corresponded to a $55 \%$ decrease in $\mathrm{MEF}_{40}$ since there was a correlation between $F V_{1}$ and $M F_{40}$ among the examined workers $\left(\mathrm{n}=73, \mathrm{r}=0.84, \mathrm{MEF}_{40}=1.7 \times \mathrm{FEV}_{1}+\right.$ 12). Increased reactivity was consequently defined as a decrease from baseline of $\mathrm{FEV}_{1}$ or $\mathrm{MEF}_{40}$ by at least $25 \%$ or $55 \%$ respectively on challenge with 10 $\mathrm{mg}$ methacholine. Workers with a reactivity intermediate increased and low were considered to have a medium reactivity to methacholine. The above definitions are visualised in fig 1 .

Table 1 shows the results of the medical investigation. Mean values of FEV 1 expressed as predicted normal were above $100 \%$ in all three groups. ${ }^{30}$ The second control group had a significantly higher value than the first control group ( $p<0.05)$, whereas there was no such difference between the exposed group and the first control group. In both the exposed group and the first control group about $40 \%$ of the workers had a greater bronchial reactivity to $10 \mathrm{mg}$ methacholine than any of the individuals in the second control group. Everyone included in this study participated on a voluntary basis. Four of 48 exposed workers and one of the 30 subjects in the first control group chose not to take part in the methacholine challenge test. The company nurse had the impression that these four exposed workers had respiratory symptoms and did not want to have these symptoms confirmed. Two of these four had a baseline $\mathrm{FEV}_{1}$ value of less than $70 \%$ of the predicted value.

The prevalence of increased methacholine reactivity was higher in the exposed group than in the first control group (chi-square test, $0.05<\mathrm{p}<$ 0.07). Figure 2 shows the distribution of

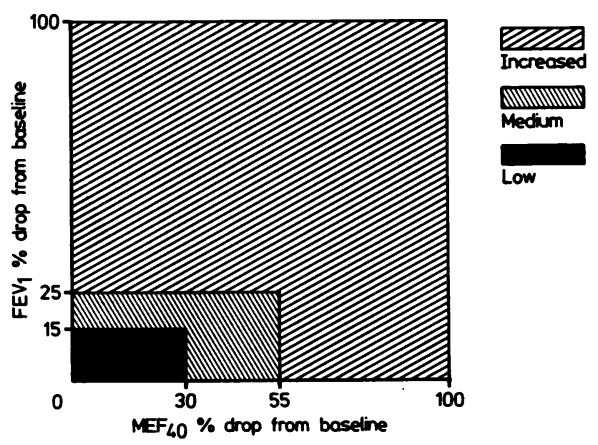

Fig 1 Definitions of grades of reactivity to $10 \mathrm{mg}$ methacholine with regard to drop from baseline of FEV, and $M E F_{40}$ 
Table 1 Results of the medical investigation: 44 exposed and 53 controls participated in the methacholine provocation test

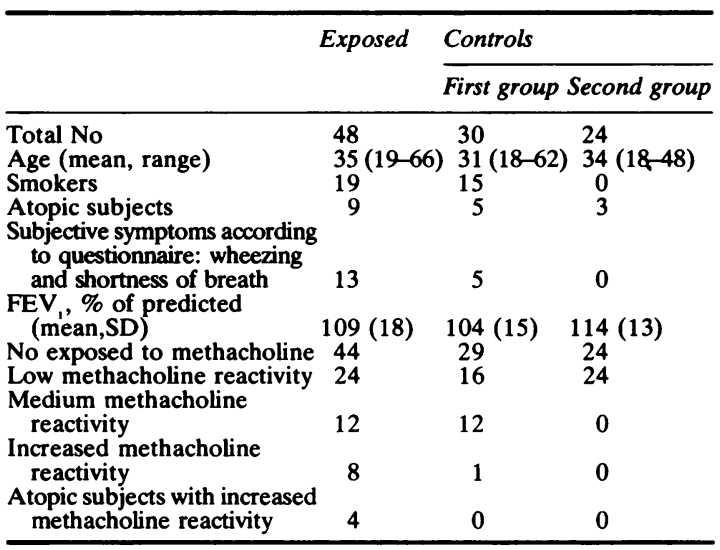

methacholine reactivity within the groups. In the exposed group there were significantly more atopic subjects among those with increased reactivity compared with this group as a whole $(\mathrm{p}<0.025)$. Isocyanate-specific IgE antibodies were not found either in serum by RAST or in the skin by prick testing. No case of bronchial asthma was identified, but wheezing and shortness of breath occasionally occured in $27 \%$ of the polyurethane workers and $17 \%$ of the controls in the second group. This difference was not statistically significant.

Twenty five workers in the exposed group reported occasional eye symptoms. As shown in fig 3 , eye symptoms were significantly more common among subjects having increased methacholine reactivity than among those with low reactivity ( $\mathrm{p}<$ $0 \cdot 05$ ). One set of symptoms appeared to be especially common: light objects seemed to have hazy contours and were surrounded by haloes of blue light. These symptoms were referred to as "blue haze" and were reported by 20 workers $(42 \%)$. This particular group of workers did not, however, have significantly more respiratory tract symptoms,

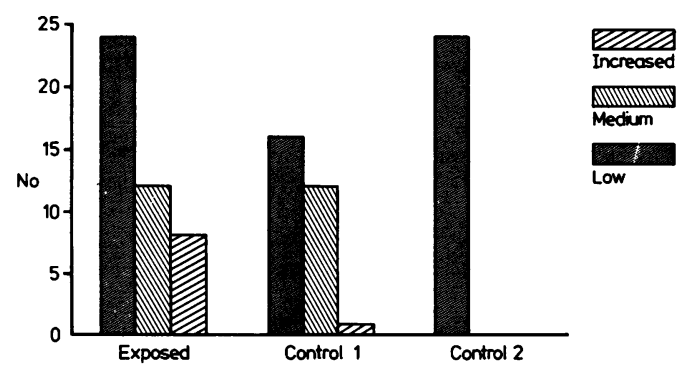

Fig 2 Distribution of methacholine reactivity in group exposed to isocyanate-amine and in two control groups.

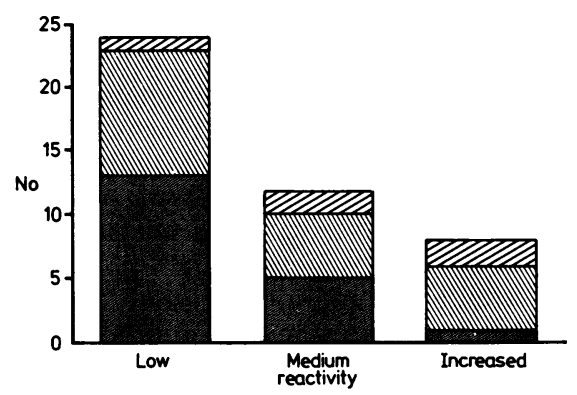

Fig 3 Methacholine reactivity and eye symptoms among individuals exposed to isocyanate-amine.

according to the questionnaire, than those without blue haze. No cases of blue haze were reported by the two control groups.

In the group of 20 workers reporting blue haze 15 experienced the symptoms when working in area $C$, two when working in area $\mathrm{A}$ or $\mathrm{B}$, and three could not give definite information on this point.

\section{WORKING ATMOSPHERE}

Air was drawn through a midget impinger filled with $10 \mathrm{ml}$ of $0 \cdot 1 \mathrm{~N} \mathrm{H}_{2} \mathrm{SO}_{4}$ absorber solution. Figure 4 shows a typical chromatogram obtained in the GLC analysis, by direct injection, of the alkalised absorber solution. Typical sampling parameters were air flow $1.5 \mathrm{l} / \mathrm{min}$ and sampling time 15 minutes with a sampling efficiency of more than $98 \%$. Figure 5 shows the results from the GLC analysis of an extracted sample containing TDI, $\mathrm{N}$-methylmorpholine, and DABCO. The extraction efficiency for TDI was about $100 \%$ with equal volumes and about $90 \%$ with an extraction volume of $1: 10$ of toluene to sample solution. The system in fig 4 was optimised for $\mathrm{N}$-methylmorpholine and DABCO in a fashion that made the TDI peak unob-

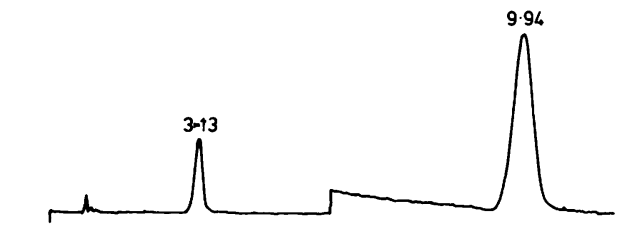

Fig 4 Chromatogram of $N$-methylmorphine $(3.13 \mathrm{~min})$ and $D A B C O$ (9.94 min). Injection of a $0.90 \mu$ laqueous alkalised $(\mathrm{pH}=10)$ sample containing $1000 \mathrm{ppm} \mathrm{NH}_{3}$. Solute concentrations were $44 \mathrm{ppm}$ and $1.1 \mathrm{ppm}$ respectively. Corresponding air concentrations were 4.8 ppm N-methylmorpholine and 0.10 ppm DABCO. Packing was $28 \%$ Pennwalt $223+4 \% \mathrm{KOH}$ on Gas Chrom $R$ (80-100 mesh); $10 \mathrm{~g}$ in a glass column $(190 \mathrm{~cm} \times 3 \mathrm{~mm}$ id). Column: $190^{\circ} \mathrm{C}$; injector: $250^{\circ} \mathrm{C}$; detector: $300^{\circ} \mathrm{C}$. Detector attenuation: $1.10^{-12}$ AFS integrator attenuation changed from $2^{8}$ after six minutes to $2^{\circ}$. 


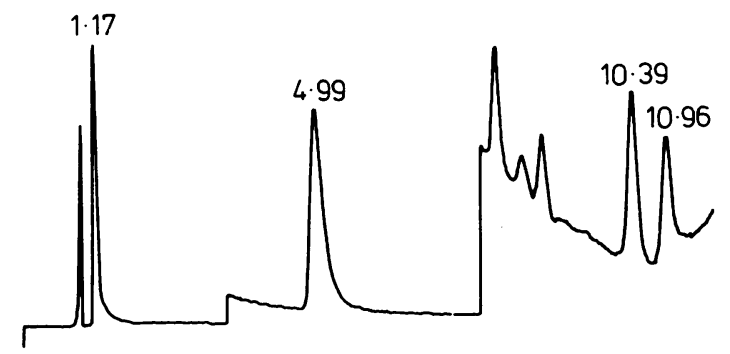

Fig 5 Chromatogram of $1.40 \mu$ loluene extracted sample: $N$-methyl-morpholine (1.17 $\mathrm{min}), D A B C O(4.99 \mathrm{~min})$, 2.6-TDA (10.39 min), and 2.4-TDA (10.96 min). Other peaks are unidentified. Solute concentrations were 4850 ppm, $39 \mathrm{ppm}, 1 \cdot 2 \mathrm{ppm}$, and $1 \cdot 2 \mathrm{ppm}$, respectively. Corresponding air concentrations were $4 \cdot 1 \mathrm{ppm}$ $N$-methylmorpholine, $0.04 \mathrm{ppm} D A B C O, 8 \cdot 1.10^{-4} \mathrm{ppm}$ 2.6-TDI and 8.7.10-4 ppm 2.4-TDI. Packing was $10 \%$ Pennwalt $223+4 \% \mathrm{KOH}$ on Gas Chrom R (80-100 mesh); $1.5 \mathrm{~g}$ in a glass column $(100 \mathrm{~cm} \times 2 \mathrm{~mm}$ id $)$. Column programmed from $90^{\circ} \mathrm{C}(2 \mathrm{~min})$ to $215^{\circ} \mathrm{C}(2 \mathrm{~min})$, $16^{\circ} \mathrm{C} /$ min. Injector: $290^{\circ} \mathrm{C}$; detector: $300^{\circ} \mathrm{C}$. Detector attenuation: $1.10^{-10} \mathrm{AFS}$ integrator attenuation changed from $2^{7}$ to $2^{1}$ after 3.5 minutes and to $2^{-5}$ after eight minutes.

servable owing to the low concentration of this compound. The air concentrations found are summarised in table 2 . A, B, and C refer to different operations in the production, as described above. The concentration of isocyanate decreased and the concentration of amines increased with the distance from the moulding. All values for TDI were well below $0.01 \mathrm{ppm}$, which is the Swedish threshold limit value (TLV). No detectable amounts of MDI or phenyl isocyanate were found using HPLC. The concentrations of $\mathrm{N}$-methylmorpholine were about 10 times the TLV in force in the Soviet Union, which is $5 \mathrm{mg} / \mathrm{m}^{3}$, corresponding to about $1 \mathrm{ppm} .^{31}$ No TLV for this substance exists in Sweden or, to our knowledge, in the United States. The TDI concentrations obtained with the HPLC and the GLC methods were in close agreement, but since only a few samples were taken simultaneously, no definite conclusions could be drawn on this point.

Table 2 Air concentrations at different stages of the production. The values are the average of several determinations. (Number of determinations in parentheses)

\begin{tabular}{|c|c|c|c|c|}
\hline \multirow[t]{2}{*}{ Work area } & \multicolumn{4}{|c|}{ Air concentrations (ppb) } \\
\hline & $\begin{array}{l}N \text {-methyl- } \\
\text { morpholine }\end{array}$ & $D A B C O$ & $\begin{array}{l}\text { TDI } \\
\text { (HPLC) }\end{array}$ & $\begin{array}{l}T D I \\
(G L C)\end{array}$ \\
\hline \multirow{2}{*}{$\begin{array}{l}\text { A (moulding) } \\
\text { B (cell crush) } \\
\text { C (removal of } \\
\text { excess foam) }\end{array}$} & $\begin{array}{ll}3 & 200(1) \\
7 & 600\end{array}$ & $\begin{array}{l}17(1) \\
46(2)\end{array}$ & $\begin{array}{l}2 \cdot 8(3) \\
1 \cdot 3(2)\end{array}$ & $\begin{array}{l}2.6(1) \\
1.7(1)\end{array}$ \\
\hline & $7600(4)$ & $110(4)$ & $1 \cdot 3(1)$ & $<1.4(4)$ \\
\hline
\end{tabular}

\section{Discussion}

The risk of respiratory complications in workers handling isocyanates has increasingly concerned industrial health specialists as there is strong evidence that they possess powerful bronchotoxic and asthmagenic properties. Criteria for TLV have been based partly on data from epidemiological studies of workers producing polyurethane, where transient and long term decrements of $F E V_{1}$ have been related to isocyanate levels. ${ }^{32-36}$ In such worker populations the exposure data are somewhat questionable because isocyanates are by no means the only gaseous irritants in polyurethane foam production that can damage the airways. Several studies indicate that exposure to amines may induce bronchial asthma. ${ }^{21-27}$ Their presence as respiratory irritants in polyurethane production may have been overshadowed by the concern about the isocyanates in these working environments. The lack of sensitive and specific analytical methods may have contributed to this, as may the difficulty in directly identifying the delayed type of an asthmatic amine response. ${ }^{26}$

We found combined work related symptoms from the eyes and the respiratory tract in a considerable number of workers exposed to the chemicals used in polyurethane production. Isocyanates and amines were the most likely causative agents. Although isocyanates are known potential sensitisers, we are inclined to believe that the amine exposure was an important cause of the symptoms, since the concentrations (ppm) of the amines were up to 10000 times higher than those of the isocyanates, which were all well below the Swedish threshold level. The similar results obtained with the HPLC and GLC methods indicate that isocyanates were probably not hydrolysed to amines in this working atmosphere, but this will be investigated in future experiments. We cannot exclude the possibility that high isocyanate concentrations may have occurred during near accidents, but on these occasions extraordinary precautions were taken to minimise exposure.

During the medical field study we searched for signs of bronchial dysfunction by challenging the workers with only two doses of nebulised methacholine. This simplified procedure is faster than the collection of dose-response data on airway sensitivity by giving a series of challenge doses. It was chosen so that workers need not be away from production for too long. Although airway sensitivity to methacholine is often studied in occupational asthma, few population studies have been reported. Thus it seemed appropriate to use two different control groups for comparison of the results. In the first control group (production workers) mean of 
baseline $F E V_{1}$, expressed as a percentage of predicted normal, was significantly lower than in control group 2 (laboratory staff). Several of the workers in the first group decreased their FEV more $_{1}$ than $15 \%$ and MEF 40 more than $30 \%$ on challenge with methacholine $(10 \mathrm{mg})$. No such reaction was seen in any of the individuals in control group 2. Tobacco smoke, pyrolysis products, and industrial chemicals other than isocyanates and amines may account for the difference between our control groups. The lack of appreciable response in any of the individuals in control group 2 is probably also due to the fact that this group basically consisted of non-atopic individuals.

The study at the workplace showed that a considerably higher proportion of the workers exposed to isocyanate-amine reacted with a drop of $F_{E V}$ or $\mathrm{MEF}_{40}$ exceeding $25 \%$ and $55 \%$ respectively from baseline on bronchial challenge with $10 \mathrm{mg}$ of methacholine than did the first control group, matched for atopy and smoking. Comparison with the results from the second control group shows an even larger difference. This is a modest increase in reactivity compared with the bronchial hyperreactivity commonly seen in established bronchial asthma however, when pronounced reactions are often elicited by 10 to 100 -fold lower doses. It is more comparable with the change of bronchial reactivity observed in healthy individuals after viral infections and exposure to $\mathrm{SO}_{2}, \mathrm{NO}_{2}$, or ozone. . $^{37-39}$

It has been suggested that any noxious agent causing mucosal damage may increase bronchial reactivity as measured by lowered threshold levels to methacholine or histamine. ${ }^{40}$ We believe that exposure to amines may cause such mucosal damage in workers producing polyurethane in a similar way to dimethylethanolamine, which has been shown to increase bronchial reactivity to histamine. ${ }^{24}$ Our suspicions concerning amines are strengthened by the fact that many of the workers also repeatedly had blurred vision, with blue haze or fog and haloes around lights. These are typical symptoms of transient oedema of the corneal epithelium and have been related to exposure to some amines, including $\mathrm{N}$-methylmorpholine. ${ }^{41-44}$ It is possible that corneal oedema (causing visual disturbances) and mucosal damage resulting in increased bronchial reactivity are common amine-induced delayed mucosal responses. The fact that eye symptoms were particularly frequent among subjects with increased methacholine reactivity seems to support this assumption. We believe that uncontrolled exposure to amine represents a substantial health hazard in workers engaged in the production of polyurethane. We suggest that risk evaluation in the polyurethane industry should include not only the occurrence of isocyanates but also the amines, since the latter substances may be present in high concentrations. Further investigations may furnish additional evidence that, in some polyurethane production, amines are the most important cause of respiratory symptoms and occupational asthma. This work will be continued by investigation of other groups of exposed workers in the Swedish polyurethane industry.

This study was supported by grants ASF 80/164 and ASF 81/0714 from the Swedish Work Environment Fund.

\section{References}

${ }^{1}$ Cockcroft, DW, Mink JT. Isocyanate-induced asthma in an automobile spray painter. Can Med Assoc J 1979;12:602-4.

${ }^{2}$ Harries MG, Sherwood Burge P, Samson M, Newman-Taylor AJ, Pepys J. Isocyanate asthma: respiratory symptoms due to 1,5-naphthlylene di-isocyanate. Thorax 1979;34:762-6.

${ }^{3}$ Butcher BT, O'Neil CE, Davies RJ, Salvaggio JE. Pre- and postshift methacholine challenge of workers manufacturing toluene diisocyanate (TDI). Am Rev Respir Dis 1979;119, suppl:204.

4 Sherwood Burge P, O'Brien IM, Harries MG. Peak flow rate records in the diagnosis of occupational asthma due to isocyanates. Thorax 1979;34:317-23.

${ }^{5}$ Butcher BT. Inhalation challenge testing with toluene diisocyanate. J Allergy Clin Immunol 1979;64:655-7.

- Sangha GK, Alarie Y. Sensory irritation by toluene diisocyanate in single and repeated exposures. Toxicol Appl Pharmacol 1979;50:533-47.

' Chester EH, Martinez-Catinchi FL, Schwartz HJ, et al. Patterns of airway reactivity to asthma produced by exposure to toluene diisocyanate. Chest 1979;75, suppl:229-31.

${ }^{8}$ Smith AB, Brooks SM, Blanchard J, Bernstein IL, Gallagher J. Absence of airway reactivity to methacholine in a worker sensitized to toluene diisocyanate (TDI). JOM 1980;22:327-31.

- Oleru UG. Respiratory function study of Nigerian workers in a TDI-based foam plant. Am Ind Hyg Assoc J 1980;41:595-9.

${ }^{10}$ Israeli R, Smirnov V, Sculsky M. Intoxication due to dicyclohexyl-methane-4-4' diisocyanate exposure. Int Arch Occup Environ Health 1981;48:179-84.

" Karol MH. Ioset HH, Alarie Y. Tolyl-specific IgE antibodies in workers with hypersensitivity to toluene diisocyanate. Am Ind Hyg Assoc J 1978;39:454-8.

${ }^{12}$ Karol MH, Sandberg T, Riley EJ, Alarie Y. Longitudinal study of tolyl-reactive IgE antibodies in workers hypersensitive to TDI. JOM 1979;21:354-8.

${ }^{13} \mathrm{Karol}$ MH, Alarie Y. Antigens which detect antibodies in workers sensitive to toluene diisocyanate. Clin Allergy 1980;10:101-9.

${ }^{14}$ Butcher BT, O'Neil CE, Reed MA, Salvaggio JE. Radioallergosorbent testing of toluene diisocyanate-reactive individuals using p-tolyl isocyanate antigen. J Allergy Clin Immunol 1980;66:213-6.

${ }^{15}$ Zeiss CR, Kanellakes TM, Bellone JD, Levitz D, Pruzansky JJ, Patterson R. Immunoglobulin E-mediated asthma and hypersensitivity pneumonitis with precipitating anti-hapten antibodies due to diphenylmethane diisocyanate (MDI) exposure. J Allergy Clin Immunol 1980;65:346-52.

${ }^{16}$ Danks JM, Cromwell O, Buckingham JA, Newman-Taylor AJ, Davies RJ. Toluene-diisocyanate induced asthma: evaluation of antibodies in serum of affected workers against a tolyl 
mono-isocyanate protein conjugate. Clin Allergy 1981;11:161-8.

17 Bauer X, Dewair M, Fruhmann G. Studies on immunological and biochemical effects of isocyanate vapours in man. Eur J Respir Dis 1981;62:128-9. Suppl No 113.

18 Belin L, Wass U. Respiratory symptoms and IgE antibodies due to isocyanate. Eur J Respir Dis 1981;62:148-9. Suppl No 113.

19 Karol MH. Survey of industrial workers for antibodies to toluene diisocyanate. JOM 1981;23:741-7.

${ }^{20}$ Sangö C, Zimerson E. A new reagent for determination of isocyanates in working atmospheres by HPLC using UV or fluoroscens detection. Journal of Liquid Chromatography 1980;3:971-90.

${ }^{21}$ Schepers GWH. Allergenic occupational air pollutants In: Frazier CA, ed. Occupational asthma. New York: Van Nostrand Reinhold, 1980:307-56.

${ }^{22}$ Pepys J, Pickering CAC. Asthma due to inhaled chemical fumes - aminoethylethanolamine in aluminium soldering flux. Clin Allengy 1972;2:197-204.

${ }^{23}$ Pepys J, Pickering CAC, London WG. Asthma due to inhaled chemical agents - piperazine dihydrochloride. Clin Allergy 1972;2:189-96.

24 Vallieres M, Cockcroft DW, Taylor DM, Dolovich J, Hargreave FE. Dimethyl ethanolamine-induced asthma. Am Rev Respir Dis 1977;115:867-71.

${ }^{25}$ Brubaker RE, Muranko HJ, Smith DB, Beck GJ. Evaluation and control of a respiratory exposure to 3(dimethylamino)propylamine. JOM 1979;21:688-90.

${ }^{26}$ Lam S, Chan-Yeung M. Ethylenediamine-induced asthma. Am Rev Respir Dis 1980;121:151-5.

${ }^{27}$ Hagmar L, Bellander T, Bergöö B, Simonsson BG. Piperazineinduced occupational asthma. JOM 1982;24:193-7.

27a Audunsson G, Mathiasson L. Simultaneous GLCdetermination of amines and isocyanates in working atmosphere. J Chromatogr 1983;261:253-64.

28 Dalene M, Mathiasson L, Jönsson JA. Trace analysis of free amines by gas-liquid chromatography. J Chromatogr 1981;207:37-46.

29 Mathiasson L, Lövkvist P. Comparison of column packings for trace analysis of free amines by gas-liquid chromatography. $J$ Chromatogr 1981;217:177-81.

${ }^{36}$ Anderhub HP, Keller R, Hergoz H. Spirometrische Unter- suchung der forcierten Vitalkapazität, Sekundenkapazităt und maximale Atemstromstărke bei 13798 Personen. Dtsch Med Wochenschr 1974;99:33-8

${ }^{31}$ Kettner H. Maximale Arbeitsplatz-Konzentrationen 1978 in der Sowjetunion. Grundlagen der Normierung. Staub-Reinhalt und der Luft 1979;39:56-62.

${ }^{32}$ Wegman DH, Peters JM, Pagnotto L, Fine LJ. Chronic pulmonary function loss from exposure to toluene diisocyanate. $\mathrm{Br} J$ Ind Med 1977;34:196-200.

${ }^{33}$ Peters JM, Murphy RLH, Ferris BG. A longitudinal study of workers exposed to toluene diisocyarate (TDI). XIV International Congress on Occupational Health, Tokyo 22-27 September 1969. Tokyo: Japan Organising Committee of XIV International Congress on Occupational Health, 1969:623-4.

${ }^{34}$ Peters JM, Murphy RLH, Pagnotto LD, Whittenberger JL. Respiratory impairment in workers exposed to "safe" levels of toluene diisocyanate. Arch Environ Health 1970;20:364-7.

${ }^{35}$ Peters JM. Studies on isocyanate toxicity. Proc $R$ Soc Med 1970;63:372-5.

${ }^{36}$ Peters JM, Wegman DH. Epidemiology of toluenediisocyanate-induced respiratory disease. Environ Health Perspect 1975;11:97-100.

37 Empey DW, Laitinen LA, Jacobs L, Gold WM, Nadel JA. Mechanisms of bronchial hyperreactivity in normal subjects after upper respiratory tract infection. Am Rev Respir Dis 1976;113:131-9.

3e Islam MS, Vastag E, Ulmer WT. Sulphur-dioxide induced bronchial hyperreactivity against acetyl-choline. Int Arch Arbeitsmed 1972;29:221-32.

${ }^{39}$ Golden JA, Nadel JA, Boushey HA. Bronchial hyperirritability in healthy subjects after exposure to ozone. Am Rev Respir Dis 1978;118:287-94.

${ }^{40}$ Boushey HA, Holtzman MJ, Sheller JR, Nadel JA. Bronchial hyperreactivity. Am Rev Respir Dis 1980;121:389-413.

${ }^{4}$ Dernehl CV. Health hazards associated with polyurethane foams. JOM 1966;8:59-62.

42 Mastromatteo E. Recent occupational health experiences in Ontario. JOM 1965;7:502-11.

${ }^{43}$ Mellerio J, Weale RA. Hazy vision in amine plant operatives. Br J Ind Med 1966;23:153-4.

4 Grant WM. Toxicology of the eye. 2nd ed. Springfield, Illinois: Charles C Thomas, 1974:14-5, 112-3, 701. 